ARTUR A. TRZEBIŃSKI

\title{
SPÓŁKI WYNAJMU RYNKU NIERUCHOMOŚCI CZY PL REITs?
}

\section{WPROWADZENIE}

Inwestycje na rynku nieruchomości wymagają od inwestorów wysokich kapitałów, które będą ulokowane na dłuższy okres, co powoduje, że rynek ten nie jest dostępny dla wszystkich. Oczywiście istnieja sposoby pozwalające na inwestowanie na rynku nieruchomości nawet nieznacznych kapitałów, ale wymaga to funkcjonowania pośrednika między inwestorem a rynkiem nieruchomości. W roli pośredników finansowych występują fundusze inwestycyjne, fundusze emerytalne i inne instytucje finansowe oraz prywatne podmioty gospodarcze. Najbardziej znaną i rozpowszechnioną grupą pośredników finansowych związanych z rynkiem nieruchomości są konstrukcje Real Estate Investmnet Trust (REITs), które można ogólnie określić jako notowane na giełdzie fundusze inwestycyjne ze zmienną liczbą akcjonariuszy ${ }^{1}$.

Jakie cechy charakterystyczne konstrukcji REITs powoduja, że sa wprowadzane do lokalnych systemów finansowych na całym świecie? Poza uprzywilejowana pozycja podatkowa REITs (podmiotowe zwolnienie z podatku dochodowego od osób prawnych lub stawka 0\%) wskazać należy również długoterminowy charakter inwestycji dokonywanych przez te podmioty, umożliwienie dostępu szerokiemu kręgowi inwestorów do rynku nieruchomości, zwiększanie transparentności rynku nieruchomości oraz wzrost bezpieczeństwa (głównie) inwestorów indywidualnych. Ważnym aspektem działalności REITs jest także zwiększanie zaangażowania lokalnego kapitału na rynku nieruchomości, który zostaje przekształcony z krótkoterminowych oszczędności w długoterminowy i stabilny kapitał.

O zasadności zaistnienia REITs w Polsce dyskutuje się od wielu lat. Dopiero w połowie 2016 r. rozpoczęto proces wprowadzania tych konstrukcji do Polski. Ministerstwo Finansów przedstawiło pierwszy projekt ustawy, który rok później po konsultacjach został zmieniony i miał być podstawą do dalszych prac legislacyjnych. Mimo że wycofano projekt ustawy z dalszych prac legislacyjnych w połowie 2017 r. i nie podjęto nowych działań w 2018 r., warto przeanalizować zaproponowane rozwiązania, szczególnie w kontekście realizacji nadrzędnego celu projektu ustawy - zwiększenie zaangażowania krajowego

${ }^{1}$ S.H. Chan, J. Erickson, K. Wang, Real Estate Investment Trust. Structure, Performance and Invest Opportunities, Oxford University Press, New York 2003. 
kapitału na rynku nieruchomości. Dlatego też celem artykułu jest wskazanie potencjalnych barier rozwoju konstrukcji PL REITs i możliwych rozwiązań, które zniwelują przeszkody w rozwoju tych konstrukcji.

\section{FUNDUSZE REITs W KRAJACH EUROPEJSKICH}

W Europie konstrukcje REITs funkcjonuja obecnie w 16 krajach i we wszystkich opierają się na obowiązku wypłaty zysków inwestorom w formie dywidendy oraz ścisłym powiązaniu z rynkiem nieruchomości. Największymi europejskimi rynkami REITs na koniec 2017 r. były: Belgia, Francja, Holandia, Wielka Brytania, Hiszpania i Turcja.

Jak wynika z przedstawionych cech charakterystycznych konstrukcji REITs funkcjonujących w krajach europejskich (tabela 1), różnią się one nieznacznie. Cechą wspólną wszystkich europejskich REITs jest brak obowiązku płacenia podatku dochodowego, który w zależności od kraju ma jedna z form: zwolnienia podmiotowego (np. Francja), obniżenia stawki podatku do poziomu 0\% (np. Belgia) lub niepobierania przy wypłacie zysków (np. Włochy). Najmniejsze zróżnicowanie występuje w zakresie poziomu przychodów, który musi zostać wypłacony akcjonariuszom. Przeważnie poziom ten wynosi 90\%. Tylko dwa kraje (Holandia i Węgry) zdecydowały się na wprowadzenie obowiązku wypłaty $100 \%$ przychodów. Przeciwne rozwiązanie przyjęły trzy kraje (Litwa, Luksemburg i Turcja), które nie określaja minimalnego poziomu wypłaty przychodów.

Tabela 1

Cechy charakterystyczne europejskich konstrukcji REITs

\begin{tabular}{|c|c|c|c|c|}
\hline $\begin{array}{c}\text { Kraj } \\
\text { (nazwa } \\
\text { konstrukcji, } \\
\text { rok } \\
\text { wprowadzenia) }\end{array}$ & $\begin{array}{c}\text { Minimalny } \\
\text { kapital } \\
\text { (mln euro) }\end{array}$ & $\begin{array}{c}\text { Restrykcje } \\
\text { inwestycyjne }\end{array}$ & $\begin{array}{c}\text { Działalnośćc } \\
\text { deweloperska }\end{array}$ & $\begin{array}{c}\text { Poziom } \\
\text { dywidendy }\end{array}$ \\
\hline $\begin{array}{l}\text { Belgia } \\
\text { (BE-REIT, } 1995 \\
\text { i 2014) }\end{array}$ & 1,2 & $\begin{array}{l}\text { Koncentracja na nieru- } \\
\text { chomościach i instru- } \\
\text { mentach finansowych } \\
\text { zwiazanych z rynkiem } \\
\text { nieruchomości. Do } 20 \% \\
\text { aktywów ogółem w jeden } \\
\text { projekt }\end{array}$ & $\begin{array}{c}\text { Tak, obiekt } \\
\text { może być } \\
\text { sprzedany po } 5 \\
\text { latach od ukoń- } \\
\text { czenia }\end{array}$ & $80 \%$ \\
\hline $\begin{array}{l}\text { Bułgaria } \\
\text { (SPC, 2004) }\end{array}$ & Brak danych & $\begin{array}{l}\text { Nieruchomości zlokalizo- } \\
\text { wane wyłącznie w Buł- } \\
\text { garii }\end{array}$ & Brak danych & $90 \%$ \\
\hline $\begin{array}{l}\text { Finlandia } \\
\text { (Finnish REIT, } \\
\text { 2009) }\end{array}$ & 5 & $\begin{array}{l}\text { Tylko wynajem i zarza- } \\
\text { dzanie nieruchomościami } \\
\text { mieszkalnymi }\end{array}$ & $\mathrm{Nie}$ & $90 \%$ \\
\hline
\end{tabular}




\begin{tabular}{|c|c|c|c|c|}
\hline $\begin{array}{l}\text { Francja } \\
(\text { SIIC, 2003) }\end{array}$ & 15 & $\begin{array}{l}\text { Do } 50 \% \text { aktywów ogółem } \\
\text { leasing }\end{array}$ & $\begin{array}{l}\text { Do } 20 \% \\
\text { aktywów } \\
\text { ogółem }\end{array}$ & $\begin{array}{l}95 \% \text { (dodatko- } \\
\text { wo } 60 \% \text { zy- } \\
\text { sków kapita- } \\
\text { łowych i } 100 \% \\
\text { dywidend) }\end{array}$ \\
\hline $\begin{array}{l}\text { Grecja } \\
\text { (REIC, 1999) }\end{array}$ & 25 & $\begin{array}{l}\text { Min. } 80 \% \text { w nieruchomo- } \\
\text { ściach. Do } 25 \% \text { aktywów } \\
\text { ogółem w jeden projekt }\end{array}$ & $\begin{array}{l}\text { Tylko } \\
\text { niepubliczne, } \\
\text { do } 40 \% \text { akty- } \\
\text { wów ogółem }\end{array}$ & $50 \%$ \\
\hline $\begin{array}{l}\text { Hiszpania } \\
\text { (SOCIMI, 2009) }\end{array}$ & 5 & $\begin{array}{l}\text { Nieruchomości zlokalizo- } \\
\text { wane w miastach }\end{array}$ & $\begin{array}{c}\text { Brak } \\
\text { ograniczeń }\end{array}$ & $\begin{array}{l}80 \% \text { (dodatko- } \\
\text { wo } 50 \% \text { zy- } \\
\text { sków kapita- } \\
\text { łowych i } 100 \% \\
\text { dywidend) }\end{array}$ \\
\hline $\begin{array}{l}\text { Holandia } \\
\text { (FBI, 1969) }\end{array}$ & 45 & Tylko pasywne inwestycje & $\begin{array}{l}\text { Do } 30 \% \text { akty- } \\
\text { wów ogółem, } \\
\text { opodatkowane }\end{array}$ & $100 \%$ \\
\hline $\begin{array}{l}\text { Irlandia } \\
\text { (REIT, 2013) }\end{array}$ & 25 & $\begin{array}{l}\text { Min. 75\% w nierucho- } \\
\text { mościach komercyjnych } \\
\text { i mieszkalnych, w tym } 3 \\
\text { nieruchomości }\end{array}$ & Brak danych & $85 \%$ \\
\hline $\begin{array}{l}\text { Izrael } \\
\text { (REIT, 2006) }\end{array}$ & Brak & $\begin{array}{l}\text { Min. } 75 \% \text { w nieruchomo- } \\
\text { ściach }\end{array}$ & $\begin{array}{c}\text { Brak } \\
\text { ograniczeń }\end{array}$ & $90 \%$ \\
\hline $\begin{array}{l}\text { Litwa } \\
\text { (REIT, 2008) }\end{array}$ & 0,04 & $\begin{array}{l}\text { Maks. 30\% aktywów } \\
\text { netto w odrębną spółkę } \\
\text { nieruchomościową lub } \\
\text { pojedynczą nieruchomość }\end{array}$ & Brak danych & $0 \%$ \\
\hline $\begin{array}{l}\text { Luksemburg } \\
(\mathrm{SIF}, 2007)\end{array}$ & 1,25 & Brak ograniczeń & $\begin{array}{c}\text { Brak } \\
\text { ograniczeń }\end{array}$ & $0 \%$ \\
\hline $\begin{array}{l}\text { Niemcy } \\
\text { (G-REITs, 2007) }\end{array}$ & 15 & $\begin{array}{l}\text { Min. } 75 \% \text { w nierucho- } \\
\text { mości (wynajem, leasing } \\
\text { i sprzedaż) }\end{array}$ & Brak danych & $90 \%$ \\
\hline $\begin{array}{l}\text { Turcja } \\
\text { (REIC, 1995) }\end{array}$ & $30 \mathrm{mln} \mathrm{TRY}$ & Tylko pasywne inwestycje & Niedozwolona & $0 \%$ \\
\hline $\begin{array}{l}\text { Węgry } \\
\text { (REIT, 2011) }\end{array}$ & $5 \mathrm{mln} \mathrm{HUF}$ & $\begin{array}{l}\text { Min. } 75 \% \text { w nieruchomo- } \\
\text { ści, do } 30 \% \text { w jeden pro- } \\
\text { jekt/obiekt }\end{array}$ & Dozwolona & $100 \%$ \\
\hline $\begin{array}{l}\text { Wielka Brytania } \\
\text { (UK-REITs, } \\
\text { 2007) }\end{array}$ & $0,7 \mathrm{mln} \mathrm{GBP}$ & $\begin{array}{l}\text { Min. } 75 \% \text { w nieruchomo- } \\
\text { ściach przeznaczonych do } \\
\text { wynajmu }\end{array}$ & $\begin{array}{c}\text { Limitowana, } \\
\text { obowiązek } \\
\text { sprzedaży po } \\
3 \text { latach (sprze- } \\
\text { daż opodatko- } \\
\text { wana) }\end{array}$ & $90 \%$ \\
\hline $\begin{array}{l}\text { Włochy } \\
\text { (SIIQ, 2007) }\end{array}$ & Nieokreślony & $\begin{array}{l}\text { Min. } 80 \% \\
\text { w nieruchomościach } \\
\text { przeznaczonych do } \\
\text { wynajmu }\end{array}$ & $\begin{array}{l}\text { Dozwolona, } \\
\text { opodatkowana }\end{array}$ & $70 \%$ \\
\hline
\end{tabular}

Źródło: opracowanie własne na podstawie EPRA Global REIT Survey 2017. A comparison of the major REIT regimes around the world; G. Mizerski, Real Estate Investment Trusts (REITs). Efektywne inwestowanie na rynku nieruchomości, CeDeWu, Warszawa 2016. 
Największe różnice występują w możliwych do realizowania przez europejskie REITs strategiach inwestycyjnych. Najbardziej restrykcyjne zasady występują w przypadku trzech państw. Fińskie REITs moga jedynie wynajmować i zarządzać nieruchomościami mieszkalnymi, niedopuszczalna jest działalność deweloperska. W Hiszpanii REITs może lokować środki w nieruchomości zlokalizowane tylko w miastach. Bułgarskie REITs moga inwestować wyłącznie w nieruchomości znajdujące się na terenie Bułgarii. Z kolei najwięcej możliwości inwestycyjnych mają francuskie SIIC, których podstawowym celem jest wynajem nieruchomości, przy czym dozwolona jest działalność deweloperska, leasing i obrót nieruchomościami; moga lokować aktywa w nieruchomości mieszkalne, biurowe, przemysłowe, hotele, centra logistyczne, opieki medycznej i turystyczne. Wskazany brak ograniczeń w działalności luksemburskich SIF wynika z faktu kierowania tych konstrukcji wyłącznie do inwestorów well informed, czyli bliżej im do prywatnych funduszy inwestycyjnych, które nie muszą przywiązywać szczególnej wagi do ochrony interesów uczestników.

Porównujac stosowane rozwiązania w krajach europejskich, można stwierdzić, że nadrzędnym celem działalności REITs w poszczególnych krajach jest wspieranie rozwoju rynków nieruchomości przy jednoczesnym utrzymywaniu wysokich standardów bezpieczeństwa inwestorów indywidualnych. Przy czym do tego wykorzystuje się inne przepisy niż te, które regulują działalność REITs.

W tym miejscu warto także zwrócić uwage na fakt wprowadzania w krajach europejskich rozwiązań w zakresie funkcjonowania konstrukcji REITs dostosowanych do lokalnych warunków. Pomimo przygotowania dwóch niezależnych od siebie modeli jednolitej konstrukcji REITs dla Europy (pierwszy z 2002 r. - Cambella i Sirmansa ${ }^{2}$ oraz drugi z 2007 - Eichholtza i Koka ${ }^{3}$ ) nie udało się wypracować jednolitych rozwiązań dla całej Europy.

\section{FUNDUSZE NIERUCHOMOŚCI W POLSCE}

Pierwszą próbę zwiększenia zaangażowania krajowego kapitału na rynku nieruchomości podjęto już w 2000 r., kiedy wprowadzono specjalistyczne fundusze inwestycyjne zamknięte. Restrykcyjne przepisy prawne ograniczajace działalność tego typu funduszy spowodowały, że żadnemu TFI nie udało się utworzyć funduszy nieruchomości. Dopiero wprowadzenie w życie nowej ustawy o funduszach inwestycyjnych w 2004 r. umożliwiło zaistnienie funduszy nieruchomości w Polsce. Od momentu uruchomienia pierwszego funduszu nieruchomości (czerwiec 2004) do połowy 2017 r. w Polsce funkcjonowało prawie

${ }^{2}$ R.D. Campbell, C.F. Sirmans, Policy implications of structural options in the development of real estate investment trusts in Europe. Lessons from the American experience, ,Journal of Property Investment \& Finance" 20(4), 2002, s. 388-405.

${ }^{3}$ P. Eichholtz, N. Kok, The EU REIT and the internal market for real estate, <https://papers. ssrn.com/sol3/papers.cfm?abstract_id=1081198> [dostęp: 10.10.2018]. 
70 funduszy nieruchomości. Zdecydowana większość z nich była funduszami inwestycyjnymi zamkniętymi aktywów niepublicznych, skierowanymi do wąskiego grona inwestorów lub wyłącznie do inwestorów instytucjonalnych. Polskie przepisy prawne nie umożliwiały tworzenia i funkcjonowania konstrukcji REITs, ale uwzględniając zwolnienie funduszy z podatku dochodowego od osób prawnych i możliwość wypłacania części zysków posiadaczom certyfikatów inwestycyjnych, można je określić jako konstrukcje o zbliżonym charakterze do REIT (REIT-like).

Trudno jest określić, ile z funkcjonujących do tej pory funduszy nieruchomości wypłacało inwestorom dywidendy. Wybór struktury funduszu zamkniętego czy aktywów niepublicznych powoduje, że zarządzający nie muszą upubliczniać informacji o działalności funduszy. Niewielka część TFI zdecydowała się na prowadzenie funduszy nieruchomości w formie publicznych funduszy (skierowanych do szerokiego kręgu inwestorów) lub dopuściła do obrotu na rynku wtórnym certyfikaty inwestycyjne. Na podstawie dostępnych informacji krajowy rynek funduszy nieruchomości można podzielić na dwie grupy funduszy. Pierwsza, w skład której wchodzą fundusze, które nie wypłacają dywidend i funkcjonuja jak klasyczne fundusze zamknięte. Druga, zawierająca fundusze, których politykę inwestycyjną oparto na wypłacie dywidend przeważnie raz w roku.

Dotychczasowe doświadczenia inwestorów z funduszami nieruchomości nie były najlepsze. Jak wykazały badania Trzebińskiego ${ }^{4}$, na sześć publicznych funduszy inwestycyjnych, które zakończyły działalność w założonym terminie, zaledwie jeden przyniósł inwestorom zysk na poziomie $23 \%$ za siedem lat. Wartość wykupowanych certyfikatów inwestycyjnych pozostałych funduszy była niższa od ceny emisyjnej (średnioroczne stopy zwrotu wyniosły od $-4,8 \%$ do $-0,2 \%)$. Na niskie i rozczarowujące wyniki funduszy inwestycyjnych wpływ miało kilka czynników, w szczególności kryzys finansowy w 2007 r. i późniejsze spowolnienie gospodarcze oraz spadek wartości nieruchomości i obniżenie stawek czynszu. Kolejnym istotnym czynnikiem były wysokie koszty funkcjonowania funduszy, których nie dostosowywano do zachodzących zmian w otoczeniu funduszy, oraz ograniczony czas funkcjonowania.

Ujemne roczne stopy zwrotu publicznych funduszy nieruchomości w latach 2012 i 2013 przełożyły się na strukturę polskiego rynku funduszy nieruchomości w następnych latach. TFI skupiły się na tworzeniu funduszy nieruchomości, koncentrując się na innych segmentach rynku nieruchomości niż obiekty mieszkalne czy biurowo-handlowe oraz na funduszach skierowanych do określonych inwestorów, przykładowo utworzono Inwestycje Rolne FIZAN (główny składnik lokat - grunty orne i łąki), Lasy Polskie FIZAN (lasy i grunty pod zalesienie), Murapol FIZ Mieszkaniowy, Trigon Profit XI FIZAN lub Kompleksowe Rewitalizacje i Odbudowa Polskich Kamieniec FIZAN. Warto dodać, że na 25 funduszy nieruchomości utworzonych w latach 2014-2017 aż sześć realizowało strategię inwestycyjną zakładającą wypłatę zysku inwe-

${ }^{4}$ A.A. Trzebiński, Assessment of Polish real estate funds liquidated at planned dates, „Central European Review of Economics and Management" 1(3), 2017, s. 67-83. 
storom, z czego cztery skierowane były także do inwestorów indywidualnych. Warto bliżej przyjrzeć się zasadom funkcjonowania dwóch funduszy, które sa najbardziej zbliżone do struktur REITs. Sa to REINO Dywidenda FIZ (początek działalności sierpień 2014) i REINO Dywidenda 2 FIZ (maj 2015). Oba fundusze inwestuja ponad $80 \%$ aktywów w nieruchomości i gwarantuja inwestorom wypłatę zysków co roku. Odpowiednio do okresu swojego funkcjonowania REINO Dywidenda wypłaciła posiadaczom certyfikatów dywidendy za lata 2014-2016 (łącznie 14 euro na certyfikat) i REINO Dywidenda 2 za 2016 r. (53 zł). Średni poziom wypłacanego zysku funduszy wynosił 91\%. Można przypuszczać, że średni poziom dywidend został utrzymany także w 2017 i 2018 r. ${ }^{5}$ Pomimo wypłacenia zysków zarządzającym tymi funduszami udało się wypracować zysk dla inwestorów, który średniorocznie (od początku działalności do czerwca 2018) wynosi odpowiednio 1,2\% i 4,7\%.

\section{KORZYŚCI Z WPROWADZENIA REITs W POLSCE}

Z dotychczasowych obserwacji rynków, na których działają REITs, wynika, że te konstrukcje są efektywnym, stabilnym i długoterminowym narzędziem do lokowania kapitału, w szczególności inwestorów indywidualnych. Inna korzyścia z REITs jest umożliwienie funduszom emerytalnym i innym inwestorom instytucjonalnym inwestycji w nieruchomości w celu dywersyfikacji portfeli inwestycyjnych z pominięciem podwójnego opodatkowania i wysokich kosztów transakcyjnych związanych z bezpośrednimi inwestycjami na rynku nieruchomości. Poza tym REITs obniżaja koszt kapitału dla lokalnych firm związanych z rynkiem nieruchomości i tym samym zwiększa się ich zdolności do konkurowania z zagranicznymi REITs, które mają uprzywilejowane formy opodatkowania. Ten aspekt REITs dla polskiego rynku nieruchomości jest szczególnie istotny ze względu na dominującą pozycję zagranicznych inwestorów na polskim rynku nieruchomości (głównie niemieckie fundusze emerytalne i amerykańskie REITs). Dodatkowo zwiększenie zaangażowania na rynku nieruchomości lokalnych firm, które korzystają z innych źródeł finansowania, przyczynia się do zwiększenia płynności rynków i stabilizacji cen.

$\mathrm{W}$ odniesieniu do polskiego rynku przedstawione powyżej korzyści z działalności REITs należy uzupełnić o możliwość współpracy OFE z REITs, co jest bardzo istotne w świetle wprowadzonych w 2014 r. ustawowych ograniczeń w zakresie inwestycji funduszy emerytalnych. Wyłączenie z katalogu dopuszczalnych lokat papierów wartościowych Skarbu Państwa spowodowało, że OFE skierowały większość posiadanych środków na rynek akcji, co zwiększyło wrażliwość funduszy emerytalnych na zmiany zachodzące na giełdzie. Współpraca REITs i OFE będzie miała dwie istotne (najważniejsze) konsekwencje. Po pierwsze, uzyskiwane wyniki inwestycyjne przez OFE będą w mniejszym

${ }^{5}$ Od kwietnia 2018 r. TFI zaprzestały upublicznianie dokumentów zawierających dane niepublicznych funduszy inwestycyjnych zamkniętych, zgodnie ze stanowiskiem KNF z marca 2018 r. 
stopniu uzależnione od koniunktury giełdowej, a tym samym powinny być bardziej stabilne w czasie. Po drugie, otwarte fundusze emerytalne jako inwestorzy instytucjonalni będą pełnić funkcje kontrolne, co z kolei podwyższy poziom i rozszerzy zakres bezpieczeństwa inwestorów indywidualnych.

Ze względu na ograniczenia artykułu uwage skupiono wyłącznie na najważniejszych aspektach wprowadzenia spółek wynajmu nieruchomości w Polsce. Szeroką analizę wpływu wprowadzenia tych spółek do polskiej gospodarki zawarto m.in. w raporcie przygotowanym przez ekspertów firmy EY ${ }^{6}$ i w opracowaniu Ruty i Adamczyk ${ }^{7}$.

\section{PLANOWANE WPROWADZENIE SPÓŁEK WYNAJMU RYNKU NIERUCHOMOŚCI}

Mając na uwadze niski poziom rozwoju rynku funduszy nieruchomości w Polsce, w październiku 2016 r. Ministerstwo Finansów przedstawiło projekt ustawy o spółkach wynajmu rynku nieruchomości (SWRN), których największą zaletą miał być uprzywilejowany status podatkowy, czyli zwolnienie z podatku dochodowego od osób prawnych. Zgodnie z projektem ustawy podmiot może uzyskać status SWRN po spełnieniu następujących warunków:

1) ma siedzibę lub zarząd na terenie Polski, kapitał zakładowy nie niższy niż $60 \mathrm{mln}$ zł i czas trwania jest nieoznaczony;

2) jest notowany na rynku regulowanym w Polsce;

3) co najmniej 70\% jego aktywów stanowią nieruchomości, akcje lub udziały w spółkach zależnych lub innych SWRN;

4) nie mniej niż 70\% przychodów netto ze sprzedaży pochodzi z najmu nieruchomości lub odpłatnego zbycia nieruchomości;

5) wartość bilansowa zobowiązań nie przekracza 70\% wartości aktywów;

6) nie mniej niż 90\% zysku powinno być wypłacane inwestorom w formie dywidendy lub reinwestowane;

7) portfel spółki powinien być zdywersyfikowany i składać się z co najmniej trzech nieruchomości, z wyłączeniem budynków mieszkalnych i lokali mieszkalnych.

Zgodnie z innymi zapisami projektu ustawy spółką zależną od SWRN jest spółka akcyjna, spółka z ograniczoną odpowiedzialnością lub spółka komandytowo-akcyjna, która spełnia wszystkie wymienione powyżej warunki z pkt 4-6 oraz dodatkowo nie mniej niż 70\% wartości jej aktywów stanowią nieruchomości i udział SWRN w kapitale zakładowym wynosi nie mniej niż 95\%. Należy dodać, że w projekcie ustawy nie przewidziano żadnych zachęt podatkowych

${ }^{6} \mathrm{EY}$, Raport analityczny $w$ zakresie nowych regulacji dotyczacych spótek rynku wynajmu nieruchomości (REIT), Warszawa 2017.

${ }^{7}$ M. Ruta, K. Adamczyk, Spótka rynku wynajmu nieruchomości-ocena projektowanej konstrukcji organizacyjno-prawnej i jej wptywu na polski rynek nieruchomości komercyjnych, „Przegląd Prawno-Ekonomiczny" 38(1), 2017, s. 141-168. 
dla inwestorów, co sprawia, że od wypłacanych dywidend będzie pobierany podatek od zysków kapitałowych.

W maju 2017 r. Ministerstwo Finansów przedstawiło nową wersję ustawy o SWRN, w której uwzględniono część uwag zgłoszonych w ramach konsultacji. Najważniejsze wprowadzone zmiany dotyczyły:

1) obniżenia kapitału zakładowego do wysokości $50 \mathrm{mln}$ zł;

2) rozszerzenia pojęcia nieruchomości o budynki mieszkalne i lokale mieszkalne;

3) zwolnienia wypłacanych dywidend z opodatkowania zarówno podatników CIT, jak i PIT;

4) obniżenia stawki CIT do poziomu 8,5\% dla przychodów SWRN uzyskanych z najmu lub zbycia nieruchomości, zbycia udziałów lub akcji spółek zależnych i otrzymywanych jako dywidendy lub przychów z udziału w spółkach zależnych.

Dodatkowo umożliwiono SWRN zatrzymanie części zysku, jeżeli w ciagu dwóch lat zostanie on przeznaczony na nabycie innej nieruchomości lub nabycie akcji/udziałów spółki zależnej. Wyeliminowano także potencjalne zagrożenie nadmiernego obrotu nieruchomościami przez SWRN wprowadzajac możliwość sprzedaży nieruchomości, które były wynajmowane przynajmniej przez 12 miesięcy.

W zakresie koncentracji kapitału w ustawie nie wprowadzono żadnych specjalnych ograniczeń. Ustawodawca skorzystał z obowiązujących przepisów dotyczących obrotu giełdowego, które zapewniają w wystarczającym stopniu rozproszenie akcjonariuszy i płynny obrót akcjami na GPW w Warszawie.

Porównanie obu projektów ustaw o SWRN pokazuje wyraźną zmianę koncepcji przywilejów podatkowych i odejście od powszechnie stosowanego rozwiązania w konstrukcjach REITs, które sprowadza się do zwalniania ich z podatku dochodowego od osób prawnych i obniżania stawki podatku dochodowego od osób fizycznych. Drugą zmianą było rozszerzenie pojęcia nieruchomości wyłącznie z sektora komercyjnego, również na sektor mieszkaniowy. Ta zmiana została wprowadzona do nowego projektu jako pomoc w realizacji celów Narodowego Programu Mieszkaniowego, w którym zakłada się zwiększenie podaży mieszkań na wynajem i zaangażowania kapitału prywatnego w finansowaniu rynku nieruchomości.

Na podstawie przyjętych w projekcie ustawy założeń należy stwierdzić, że SWRN spełniały prawie wszystkie podstawowe warunki wymagane od funduszy REITs, czyli inwestycje na rynku nieruchomości i uzyskiwanie przychodów głównie z wynajmu nieruchomości, wypłata zysku w formie dywidend i notowanie na rynku regulowanym jako spółka akcyjna. Natomiast najważniejsza różnica między SWRN a REITs odnosi się do poziomu zwolnienia z podatku CIT. Ogólnie przyjmuje się, że REITs są podmiotowo zwolnione z podatku dochodowego CIT lub podlegają obniżonej stawce 0\% (wyjątkiem są greckie REITs obciążone podatkiem CIT w wysokości poniżej 1\%). W Polsce zaproponowano rozwiązanie obniżonej stawki podatku do wysokości $8,5 \%$ w celu wyeliminowania faworyzowania grupy podmiotów prowadzących działalność gospodarczą. Osoby fizyczne wynajmujace posiadane nieruchomości obciążone sa zryczałtowanym podatkiem w takiej wysokości. 


\section{BARIERY ROZWOJU SWRN I SPOSOBY ICH USUNIĘCIA}

Majac na uwadze propozycje ustawy o SWRN, zgłoszone uwagi do projektu przez podmioty opiniujace i wypracowane zasady działania konstrukcji REITs w krajach europejskich, należy się zastanowić, jaki model SWRN będzie optymalny dla polskiego rynku nieruchomości. Celem nadrzędnym projektodawcy jest zwiększenie atrakcyjności sektora rynku nieruchomości na wynajem i zwiększenie zaangażowania polskiego kapitału na tym rynku. W tym miejscu warto zadać pytanie, czy proponowane w projekcie ustawy o SWRN rozwiązania spełnią oczekiwania projektodawcy. W drugim projekcie ustawy o SWRN Ministerstwo Finansów przyjęło tylko część uwag zgłaszanych przez podmioty opiniujące, pozostawiając bez zmiany przepisy, które moga skutecznie blokować rozwój rynku SWRN w Polsce (przede wszystkim wysokość kapitałów własnych) lub przyczyniać się do nadużywania SWRN (m.in. możliwość prowadzenia działalności deweloperskiej przy obniżonej stawce CIT, opisana niżej). W dalszej części pkt VI przedstawiono potencjalne bariery rozwoju rynku SWRN w Polsce i wskazano rozwiązania, które powinny przyczynić się do zwiększenia atrakcyjności i efektywności SWRN.

Pierwszą i największą barierą rozwoju rynku SWRN w Polsce jest wysokość kapitału zakładowego, którego wysokość ma być nie niższa niż $50 \mathrm{mln}$ zł. Zdaniem podmiotów opiniujacych projekt (Stowarzyszenie REIT Polska, BBC i Konferencja Lewiatan) proponowany wymóg kapitałów jest niedostosowany do krajowych realiów i przekracza możliwości zdecydowanej części podmiotów. Zbliżone minimalne wartości kapitałów wymagane są od podmiotów działających w bogatych krajach (np. Niemcy, Francja, Holandia) z wysoko rozwiniętymi rynkami REITs. Ministerstwo Finansów uzasadnia zaproponowana wysokość kapitału zakładowego potrzebą ochrony interesów nabywców akcji SWRN i możliwymi problemami w działalności SWRN z niższymi kapitałami. W przeciwieństwie do uwag zgłaszanych przez podmioty opiniujace projekty ustaw (Stowarzyszenie REIT Polska, BBC czy Konfederacja Lewiatan) w zakresie znacznego obniżenia kapitałów zakładowych SWRN, autor staje na stanowisku utrzymania wysokich standardów kapitałowych SWRN. Rozsądnym rozwiązaniem jest zastapienie kapitałów zakładowych na minimalnym poziomie $50 \mathrm{mln}$ zł kapitalizacją giełdową na poziomie $60 \mathrm{mln}$ zł lub równowartością w złotych $15 \mathrm{mln}$ euro, co zapewni zgodność z przepisami stosowanymi na GPW w Warszawie, przy jednoczesnym posiadaniu kapitałów własnych na poziomie nie niższym niż równowartość w złotych 5 mln euro i zwiększaniu go o 1 mln euro na każdą utworzoną spółkę zależna. Taka konstrukcja kapitałów zakładowych spowoduje, że SWRN będą tworzone nie tylko przez największych inwestorów instytucjonalnych, ale również przez średnie podmioty krajowe. Dodatkowo zbliży SWRN do innych instytucji funkcjonujaccych w Polsce (przykładowo kapitały zakładowe dla banku wynosza min. $5 \mathrm{mln}$ euro, dla towarzystw funduszy inwestycyjnych i alternatywnych spółek inwestycyjnych - min. 0,25 mln euro i maks. $10 \mathrm{mln}$ euro). Z kolei wymóg zwiększania kapitałów zakładowych w przypadku tworzenia spółek zakładowych pozwoli na 
ograniczenie tworzenia wielu spółek zależnych w krótkim czasie, a tym samym pozwoli na zwiększenie efektywności finansowej struktury SWRN i spółek zależnych.

Drugim ograniczeniem jest możliwość nabywania wyłącznie prawa do nieruchomości o uregulowanym stanie prawnym i niebędących przedmiotem zabezpieczenia lub egzekucji. Zapis ten zbliżony jest do ograniczenia wprowadzonego w $2000 \mathrm{r}$. w odniesieniu do funduszy inwestycyjnych (ustawa z 16 listopada 2000 r. o zmianie ustawy o funduszach inwestycyjnych). Restrykcyjny przepis skutecznie uniemożliwiał utworzenie funduszy inwestycyjnych lokujacych aktywa na rynku nieruchomości. Dopiero zmiana wprowadzona w $2004 \mathrm{r}$. (ustawa z 27 maja 2004 r. o funduszach inwestycyjnych), która polegała na umożliwieniu funduszom nabywania nieruchomości obciążonych wyłącznie takimi prawami osób trzecich, których realizacja nie spowoduje ryzyka utraty własności nieruchomości, przyczyniła się do tworzenia i funkcjonowania krajowych funduszy nieruchomości. W praktyce często się zdarza, że nieruchomości przeznaczone do sprzedaży są zabezpieczeniem utworzonym na potrzeby zabezpieczenia np. kredytu bankowego. Utrzymanie tego zapisu powoduje, że SWRN musi odstapić od transakcji, chociaż ten sam bank zapewniałby finansowanie transakcji nabycia tej nieruchomości. A tymczasowe zwalnianie zabezpieczenia na czas przeprowadzenia transakcji może być tak skomplikowane i zwiększające koszty transakcyjne, że SWRN odstapi od transakcji. Należałoby rozważyć zmiany w warunku odnoszacym się do nieruchomości i wprowadzenie rozwiązania przewidzianego dla funduszy inwestycyjnych, czyli SWRN powinny mieć możliwość nabywania nieruchomości będących przedmiotem zabezpieczenia, jeżeli nie ogranicza ono prawa własności.

Innym aspektem tego zapisu jest zawężenie możliwych inwestycji przez SWRN tylko do zakupu nieruchomości, która określona jest jako budynek trwale związany z gruntem lub część takiego budynku, co blokuje zakup gruntów. Wyłączenie tego rodzaju nieruchomości może przyczynić się do utraty części potencjalnych nieruchomości generujących przychody z najmu, takich jak przede wszystkim grunty dzierżawione pod obiekty handlowe (chodzi o sytuacje, gdy właścicielem gruntu jest SWRN, a właścicielem budynku jest inny podmiot). Można domniemywać, że to ograniczenie związane jest z uniknięciem nadmiernego obrotu gruntami przez SWRN, przy czym ten zapis powoduje zmniejszenie potencjalnych przychodów SWRN i zawęża możliwość dywersyfikacji inwestycji. Z drugiej strony zapis odnoszacy się do posiadania przez SWRN i spółkę zależną minimum 70\% aktywów bilansowych w nieruchomościach może spowodować, że spółki zależne będą nabywały grunty lub prowadziły działalność deweloperska. W przeciwieństwie do przepisów stosowanych w krajach europejskich w polskim projekcie nie ma jednoznacznego zapisu odnoszącego się do możliwości prowadzenia działalności deweloperskiej lub jej zakazu. Czytając literalnie zapis o posiadaniu minimum 70\% aktywów bilansowych w nieruchomościach przez spółki zależne, można stwierdzić, że spółki zależne mogą prowadzić „ukryta” działalność deweloperską pod warunkiem posiadania innego obiektu (obiektów). W świetle tej uwagi oraz poziomu rozwoju krajowego rynku nieruchomości zasadne jest umożliwienie prowadze- 
nia działalności deweloperskiej spółkom zależnym, przy ograniczeniu jej do $30 \%$ wartości bilansowej aktywów SWRN z możliwością sprzedania dopiero po trzech latach i opodatkowaniu (jak np. w Wielkiej Brytanii, Holandii czy Francji).

Kolejną przeszkodą w funkcjonowaniu SWRN okazać się może możliwość sprzedaży posiadanych nieruchomości przez SWRN. Po pierwsze, obowiązek posiadania minimum $70 \%$ aktywów bilansowych w nieruchomościach powoduje, że SWRN, korzystając z prawa sprzedaży nieruchomości, może nie spełnić tego warunku. Proces sprzedaży i nabywania nowej nieruchomości jest procesem długotrwałym i trudno będzie przeprowadzić w krótkim odstępie czasu te dwie czynności, w szczególności przed końcem roku kalendarzowego. Po drugie, możliwość sprzedaży nieruchomości przez SWRN po minimum 12 miesiącach wynajmu może być wykorzystywana przez podmioty, których główną działalnością jest obrót nieruchomościami, a nie ich długoterminowy wynajem: np. podmiot nabywa nieruchomość, której jest właścicielem przez wymagane 12 miesięcy, i w 13 miesiącu finalizuje umowę sprzedaży, która zawarł kilka miesięcy wcześniej. Taki podmiot nie spełnia podstawowego celu ustawy, którym jest zwiększenie atrakcyjności podejmowania i prowadzenia działalności gospodarczej na polskim rynku nieruchomości. Takie działania zapewne zachęca do prowadzenia działalności spekulacyjnej, częstych wahań cen nieruchomości i zmniejszenia zaufania inwestorów do SWRN. Z tymi wątpliwościami powiązany jest także warunek posiadania minimum $70 \%$ wartości bilansowej aktywów wyłącznie w nieruchomościach.

Wymienione trzy potencjalne zagrożenia dla rozwoju rynku SWRN w Polsce sa ze sobą powiązane i można je łatwo wyeliminować. SWRN i spółki zależne powinny mieć możliwość zaliczenia jako aktywa bilansowe środków pieniężnych lub należności wynikających ze sprzedaży posiadanych nieruchomości w sytuacji, gdy środki zostaną przeznaczone na nabycie lub wybudowanie nowej nieruchomości lub przeznaczone na wypłatę dywidend. Jednocześnie okres posiadania i wynajmowania nieruchomości powinien być wydłużony do minimum trzech lat w celu wyeliminowania głównie działań spekulacyjnych.

Należy odnieść się do proponowanych przez podmioty opiniujące zmian w wysokości poziomu dywidendy. Według Stowarzyszenie REIT Polska, BBC czy EY poziom wypłacanych dywidend powinien zostać obniżony do $80 \%$ zysku za ostatni rok obrotowy z możliwością reinwestycji zysku pochodzącego ze sprzedaży nieruchomości. Zdaniem autora poziom dywidend powinien zostać na proponowanym w projekcie poziomie $90 \%$, pod warunkiem zmiany definicji nieruchomości i umożliwienia prowadzenia działalności deweloperskiej przez spółki zależne. Na przykład działający od 2014 r. fundusz nieruchomości REINO Dywidenda FIZ w latach 2014-2016 co roku wypłacał dywidendy na poziomie odpowiednio $100 \%, 92 \%$ i $91 \%$ rocznego zysku, co nie spowodowało zakłóceń w działalności tego funduszu. Dodatkowo aż osiem krajów europejskich ma wymóg wypłaty minimum $90 \%$ zysku i są to kraje z rynkami REITs na różnym poziomie rozwoju. Podmioty opiniujace rekomendowane obniżenie poziomu dywidendy argumentują faktem wprowadzania SWRN do Polski i pozytywnym wpływem zmniejszonego obciążenia na rozwój SWRN. W sytuacji 
gdy SWRN ma możliwość zatrzymania zysku w celu jego reinwestowania, wysokość wypłaty dywidend ma drugorzędne znaczenie. Spodziewać się należy, że SWRN będą dążyły do wypłacania jak najwyższych możliwych dywidend, aby pozyskać jak najwięcej inwestorów i kapitałów oraz zwiększyć atrakcyjność kolejnych emisji akcji.

Uwagę należy zwrócić także na nieuwzględniony w projekcie ustawy wpływ tworzenia SWRN na rynek funduszy nieruchomości. Wprowadzenie SWRN z jednoczesnym wprowadzeniem opodatkowania działalności funduszy inwestycyjnych (od stycznia 2017 r.) zahamuje rozwój rynku funduszy nieruchomości w Polsce, a nawet może spowodować likwidowanie funduszy ze względu na niekorzystne rozwiązania podatkowe. SWRN mające obowiązek wypłaty dywidend i korzystajace z obniżonej stawki CIT będą nie tylko substytucyjne w stosunku do funduszy nieruchomości, ale także ich konkurentami. Publiczne fundusze nieruchomości, czyli kierowane do szerokiego kręgu inwestorów i mające obowiązek upubliczniania informacji o prowadzonej działalności przestaną mieć rację bytu w Polsce. Nałożenie na fundusze nieruchomości obowiązu podatkowego spowoduje obniżenie uzyskiwanych przez nie stóp zwrotu, a tym samym odpływ inwestorów do SWRN. Rekomendowanym rozwiązaniem, które przyczyni się zarówno do rozwoju rynku SWRN, jak i rynku funduszy nieruchomości, jest umożliwienie współpracy między tymi podmiotami oraz zrównanie ich na poziomie wysokości podatków dochodowych. Można to zilustrować przykładem: Arka BZ WBK Fundusz Rynku Nieruchomości po ogłoszeniu zamiaru sprzedaży posiadanych obiektów otrzymywał oferty zakupu z cenami, które były znacznie niższe niż wartości rynkowe tych nieruchomości. Podobne problemy ze spieniężeniem posiadanych nieruchomości miały także inne publiczne fundusze nieruchomości. W momencie funkcjonowania na rynku SWRN moga one być potencjalnymi nabywcami nieruchomości od funduszy, co powinno skrócić okres sprzedaży nieruchomości i zapobiec zaniżaniu cen transakcyjnych. Z kolei fundusze nieruchomości, nie mając ograniczeń w zakresie działalności deweloperskiej, mogą dostarczać na rynek nowe obiekty, jak również nabywać od SWRN nieruchomości.

\section{PODSUMOWANIE}

Propozycja wprowadzenia SWRN w Polsce jest dobrym kierunkiem zmian w finansowaniu rynku nieruchomości i zwiększeniu zaangażowania krajowych podmiotów na tym rynku. Przy czym należy zwrócić uwagę, że przedstawiony projekt ustawy jest zbyt ogólny i niektóre zawarte w nim zapisy zamiast stymulować rozwój rynku nieruchomości mogą mieć odwrotny wpływ. Przykładowo wymóg kapitałów zakładowych na poziomie $50 \mathrm{mln}$ zł ograniczy liczbę podmiotów zainteresowanych tworzeniem SWRN czy możliwość prowadzenia działalności deweloperskiej przez spółkę zależną od SWRN, która w zamyśle autorów projektu ustawy jest zakazana dla SWRN i spółek zależnych. 
Trudno przewidzieć, jak wprowadzenie przepisów prawnych w proponowanej formie wpłynie na zwiększenie zaangażowania krajowych podmiotów na rynku nieruchomości. Uwzględniając proponowane w projekcie rozwiązania, SWRN mogą spotkać się z zainteresowaniem tylko dużych inwestorów, którzy dysponuja odpowiednim zapleczem finansowym. Można także odnieść wrażenie, że SWRN z uprzywilejowaną pozycją podatkowa mają być zachęta dla podmiotów do budowania nowych nieruchomości i zachętą do tego ma być obniżona stawka podatku dochodowego dla SWRN. Z drugiej strony wprowadzenie SWRN bez uwzględnienia rynku funduszy inwestycyjnych już działających na rynku nieruchomości może przyczynić się do rozwoju rynku SWRN i jednoczesnego zahamowania, a nawet całkowitej likwidacji, rynku funduszy nieruchomości w Polsce.

Reasumując, należy stwierdzić, że proponowany projekt ustawy o SWRN spotka się przede wszystkim z zainteresowaniem firm deweloperskich, które wykorzystają SWRN do optymalizacji przychodów i kosztów w ramach swoich grup kapitałowych. Z kolei zmiana niektórych przepisów, w szczególności odnośnie do wysokości kapitałów i obowiązków podatkowych dla funduszy inwestycyjnych, może zachęcić nowe podmioty do rozpoczęcia działalności na rynku nieruchomości, a tym samym zwiększyć napływ nowego kapitału. Dodatkowo pobudzanie rozwoju relacji między rynkiem SWRN i funduszy nieruchomości (w zakresie finansowania ich działalności czy zwiększania liczby podmiotów w transakcjach kupna-sprzedaży nieruchomości) przyczyni się nie tylko do zwiększania obu tych rynków, lecz także do zwiększenia transparentności rynku nieruchomości i pozwoli inwestorom indywidualnym na dokonywanie wyborów w zakresie inwestycji pośrednich na tym rynku.

dr Artur A. Trzebiński

Uniwersytet Ekonomiczny we Wroctawiu

artur.trzebinski@ue.wroc.pl

https://orcid.org/0000-0002-1448-454X

\author{
REAL ESTATE LEASING COMPANIES \\ OR REAL ESTATE INVESTMENT FUNDS?
}

Summary

In the mid-2016, the first unsuccessful attempt to introduce REITs into the national legislation was made. In May 2017, the Ministry of Finance introduced a revised draft on real estate leasing companies (SWRN law) whose construction is similar to REITs. In the view of the opinion-making bodies, which is shared by the author of this article, the adoption of the SWRN law in the form proposed by the Ministry of Finance may produce results other than desired. Instead of increasing the involvement of domestic capital in the real estate market, SWRNs may be used to support tax evasion and effectively stop the development of the real estate investment funds market in Poland. Therefore, in order to eliminate these dangers, certain modifications of the rules of the operation of SWRNs based on SWRN law and changes in the manner of operation of the existing real estate investment funds in Poland as well as solutions used in European countries were proposed. 
